\title{
Interpersonal conflict, job satisfaction, and team effectiveness among nurses at Ismailia General Hospital
}

\author{
Wafaa A. El-Hosany * \\ Department of Nursing Administration, Faculty of Nursing, Suez Canal University, Ismailia, Egypt
}

Received: April 27, 2016

DOI: $10.5430 /$ jnep.v7n3p115
Accepted: September 18, $2016 \quad$ Online Published: November 13, 2016

URL: http://dx.doi.org/10.5430/jnep.v7n3p115

\begin{abstract}
Background and objective: Interpersonal conflict is considered as a daily challenge in a healthcare setting. Nurses with interpersonal conflict usually complained from poor job satisfaction. This study aimed to determine the correlations between interpersonal conflict, job satisfaction, and team effectiveness, to evaluate the differences between nurses with and without conflicts and to stratify the variables that predict interpersonal conflict.

Methods: The studied sample (200 nurses) was estimated based on Cochran formula. The sample was divided into 2 groups: study group (nurses with conflicts; $n=147$ ), and control group (nurses without conflicts; $n=53$ ). Data collection performed by 3 questionnaires: Interpersonal Conflict, Job Satisfaction, and Team Effectiveness Questionnaire (TEQ). Interpersonal Conflict scores $\geq 60 \%$ indicates presence of conflict, while scores $<60 \%$ indicates absence of conflict. Satisfactory levels were stratified into satisfied (scores 32-42) and dissatisfied (scores 10-31). TEQ scores were classified into high $(\geq 60 \%)$ and low $(<60 \%)$ team effectiveness.

Results: Incidence of interpersonal conflicts among the studied nurses was $73.5 \%$. There were significant negative correlations between interpersonal conflict, job satisfaction and team effectiveness, whereas, there were significant positive correlations between TEQ and job satisfaction. The scores of job satisfaction and TEQ were significantly lower among study group compared to control group. Using regression analysis, age $(\beta=-0.26, p=.02)$, experience $(\beta=-0.41, p<.0001)$, and job satisfaction $(\beta=$ $-0.12, p=.029)$ were significant negative predictors of interpersonal conflict.

Conclusions: Interpersonal conflict negatively correlated with job satisfaction and team effectiveness. There were significant differences between studied groups regarding demographics, job satisfaction, and TEQ.
\end{abstract}

Key Words: Relationship conflict, Nursing staff, Teamwork

\section{INTRODUCTION}

Healthcare systems are considered to be large organizations. ${ }^{[1]}$ In several organizations, conflict represents a prevalent and a serious issue. ${ }^{[2]}$ It has adverse effects on organization's function and results in loss of efficient staff. ${ }^{[3]}$ The conflict as an internal or external discord results from differ- ences in the idea, values or feelings between two or more persons. ${ }^{[4]}$ Several potential factors may predispose to the conflict that includes different personal backgrounds, values, beliefs, and goals. When the conflict managed properly, it can promote organizational creativity and lead satisfaction for all involved parties. ${ }^{[5]}$

\footnotetext{
*Correspondence: Wafaa A. El-Hosany; Email: drwafaadr@yahoo.com; Address: Department of Nursing Administration, Faculty of Nursing, Suez Canal University, Ismailia, Egypt. 
Interpersonal conflict is one of the major types of conflict; it is known as relationship conflict. This conflict centers on individual differences and the social and emotional relationships that accompany them. There are many causes of conflict that include poor communication, unclear expectations, conflicts of interest, competition over resources, performance deficiencies, staffing changes, diversity in gender, culture, or age. ${ }^{[6]}$ Interpersonal conflict is caused by the tension between team members due to real or perceived difference. ${ }^{[7]}$ Interpersonal conflict is considered severe and harmful, and it has several adverse effects. While working in a safe environment is important, ${ }^{[8]}$ interpersonal conflict can lead to hostile relationships and in turn increase work pressure. ${ }^{[9]}$ The consequences of interpersonal conflict are so devastating that it can't be imagined to have any positive impact. ${ }^{[10]}$ In one recent Egyptian study, Higazee ${ }^{[11]}$ reported that nurses experienced a moderate degree of interpersonal conflict in governmental hospitals. In Iranian study, Mahdian and Yari ${ }^{[10]}$ found that there are significant and direct correlations between interpersonal conflict and job outcomes. Several studies reported that interpersonal conflict was associated with poor work-related attitudes and job dissatisfaction, organizational commitment, turnover intentions, negative emotions, and emotional exhaustion. ${ }^{[12-15]}$ Demsky ${ }^{[16]}$ indicated that interpersonal conflict was related to decreased life and job satisfaction and increased burnout.

In contrast to interpersonal conflict, nurse satisfaction with the workplace is an essential factor for the successful organization. ${ }^{[17]}$ Similarly, effective teamwork in the nursing care setting promote job satisfaction, ${ }^{[18-20]}$ stimulate decisionmaking ${ }^{[21]}$ and optimize patients' outcome. ${ }^{[22,23]}$ The relationships between teamwork processes and job satisfaction were examined, and it was found that effectiveness of teamwork is related to job satisfaction and mental health of staff members. ${ }^{[24]}$ In one Jordanian study, Al-Khasawneh and $\mathrm{Moh}^{[25]}$ observed that there was a significant positive relationship between nursing performance, job satisfaction, and safe organizational climate. The study of Hamaideh ${ }^{[26]}$ found a negative correlation between job satisfaction and burnout of nurses working at health sections in Jordan.

Teamwork and team effectiveness have become necessary to achieve positive, cost-effective results in various organizational settings. ${ }^{[4,27]}$ Regarding the interaction between teamwork and interpersonal conflict, it has been suggested that there is a negative relationship between them. The extent of this relationship is estimated to be $1 \%-8 \%$ of the total relationships in the organization. ${ }^{[28]}$ In the same prospect, interpersonal conflict affects team effectiveness at various levels. The conflict usually associated with lower team effectiveness, reduced nursing well-being and increased turnover. ${ }^{[29]}$
Interpersonal conflict may eventually regress the process of team effectiveness and delay the team to reach their intended aims. ${ }^{[30]}$ The team-leader must possess effective communication skills, conflict-resolution skills, to minimize and manage the interpersonal conflict among nurses. ${ }^{[17,31]}$

\subsection{Significance of the study}

The significance of this study is that it can expand our knowledge about the relationships between interpersonal conflict, job satisfaction, and team effectiveness. Future research on the predictors of these variables are needed. ${ }^{[32,33]}$ Furthermore, previous studies regarding negative correlations of interpersonal conflict in nursing settings are scarce. A hypothetical pivotal question in that sort of studies is: how do nurses in healthcare organization perceive the amount of their interpersonal conflict? Moreover, infrequent researches have been done on the intercorrelations between nursing satisfaction and team effectiveness.

Dissatisfaction of nurses negatively affects their performance and positively induce nursing turnover. ${ }^{[34]}$ Organizational turnover could contribute to the nursing shortage. In Egypt, few studies were conducted in the area of conflict. Therefore, it is important to implement this research, where it may help the nursing supervisors to invent strategies for management of interpersonal conflict. These management strategies will have a positive influence on the nursing performance and satisfaction toward the job.

\subsection{The aim of the study}

This study performed in two stages. The first-stage study aimed to assess the incidence of interpersonal conflict among nurses at Ismailia General Hospital and to determine the correlations between interpersonal conflict, job satisfaction, and team effectiveness.

\subsection{Hypothesis}

Four hypotheses were generated:

- Hypothesis 1: "The nurses working at Ismailia General Hospital had a high incidence of interpersonal conflict”.

- Hypothesis 2: "There is a significant negative correlation between interpersonal conflict and job satisfaction".

- Hypothesis 3: "There is a significant negative correlation between interpersonal conflict and team effectiveness".

- Hypothesis 4: "There is a significant positive correlation between job satisfaction and team effectiveness".

The second-stage study aimed to evaluate the differences between the nurses with interpersonal conflict and the nurses 
without interpersonal conflict and to stratify the variables that predict the interpersonal conflict among the recruited nurses.

Four hypotheses were generated:

- Hypothesis 5: "There are significant differences between the nurses with interpersonal conflict and the nurses without interpersonal conflict regarding demographic data".

- Hypothesis 6: "There are significant differences between the nurses with interpersonal conflict and the nurses without interpersonal conflict regarding job satisfaction scores".

- Hypothesis 7: "There are significant differences between the nurses with interpersonal conflict and the nurses without interpersonal conflict regarding team effectiveness scores".

- Hypothesis 8: "Demographic characteristics, job satisfaction, and team effectiveness are significant predictors of interpersonal conflict".

\section{SUBJECTS AND METHODS}

\subsection{Technical design}

The technical design included the research aim, design, sample, setting, and data collection tools.

\subsection{Study design}

The first-stage study designed as descriptive-correlational research while the second-stage study structured as nested case-control study.

In this design, some number of controls are selected and compared to the incident cases. The nested case-control model is more efficient than a case-cohort design with the same number of selected controls. ${ }^{[35]}$

\subsection{Study sample}

Total population consists of 488 nurses working in Ismailia General Hospital during the year 2014. The first-stage sample was estimated based on Cochran formula as 200 nurses. Two groups of subjects enrolled in the second-stage study. The first group (cases or study group) included the nurses who had interpersonal conflicts $(n=147)$ and the second group (control group) included the nurses who didn't have interpersonal conflicts $(n=53)$.

\subsection{Study setting}

The study conducted at Ismailia General Hospital, Ismailia Governorate, Egypt and included 200 actively working female nurses with a minimum one year of experience. Nurses enrolled from the following departments/units: Internal Published by Sciedu Press
Medicine, General Surgery, Pediatrics, and Obstetrics \& Gynecology Departments, and Emergency, Dialysis, and Intensive Care Units (ICUs), and Major Operation Theater. Nurses in these departments have a high degree of conflict as observed during clinical rounds and reported by training interns.

\subsection{Tools of the study}

Data collection performed by three standardized questionnaires: Interpersonal Conflict Questionnaire, Job Satisfaction Scale, and TEQ.

\subsubsection{Interpersonal conflict questionnaire}

The included nurses filled out the self-assessment questionnaire of interpersonal conflict, which consists of 35 questions. The response includes three-point scale; never (0), sometimes (1), and always (2). The total score ranged from 0-70. Scores $\geq 60 \%$ indicates interpersonal conflict, while scores $<60 \%$ indicates no interpersonal conflict. ${ }^{[36]}$

\subsubsection{Job Satisfaction Scale}

Job satisfaction level of the nurses was measured by Job Satisfaction Scale that consists of 10 questions. The nurses responded by one of five Likert scale responses: strongly disagree (1), disagree (2), neutral (3), agree (4), strongly agree (5). The total score ranged from 10-50. The satisfaction score was interpreted as follows: $42-50$ very high satisfactory level, 39-41 high satisfactory level, 32-38 average, satisfactory level, 27-31 low satisfactory level, 10-26 and very low satisfactory level. ${ }^{[37]}$ The satisfactory levels were joined into only two categories satisfied (very high, high and average satisfactory levels) and dissatisfied (low and very low satisfactory levels).

\subsubsection{Team Effectiveness Questionnaire (TEQ)}

The investigator measured team effectiveness among staff nurses using TEQ, which consists of 56 questions. The questionnaire includes eight dimensions: (1) purpose and goals, (2) roles, (3) team processes, (4) team relationships, (5) intergroup relations, (6) problem-solving, (7) passion and commitment (cohesion), and (8) skills and learning. Every dimension contains seven questions. The nurses responded by one of five Likert scale responses: strongly disagree (1), disagree (2), neutral (3), agree (4), strongly agree (5). The score of each dimension equals the average of the seven questions (range 1-5). The total score ranged from 8-40. ${ }^{[38]}$ The TEQ scores were classified into high team effectiveness ( $\leq$ $60 \%)$ and low team effectiveness $(<60 \%)$.

\subsection{Operational design}

This part of the study included the preparatory phase, the validation of tools, the pilot study, and the field work phase. 


\subsection{Preparatory phase}

The tools were translated into the Arabic Language to make it easy and clear to nursing staff.

\subsection{Validation of tools}

The content validity (or logical validity) performed to measure the extent to which the tools represent all facets of the social psychometrics construction. The method of measuring content validity were carried out by gauging agreement among judges (professors of Nursing Administration) regarding how essential of a particular item of the tools is. ${ }^{[39]}$

Each of the subject matter expert raters (SMEs) on the judging panel respond to the following question for each item: "Is the knowledge or practice measured by this item 'essential', 'useful, but not essential' or 'not necessary' to the performance of the construct?" If more than half the panelists indicate that an item is essential, that item has content validity. Greater levels of content validity exist as larger numbers of panelists agree that a particular item is essential. The recommended modifications performed and the tools tested through the pilot study.

\subsection{Pilot study}

A pilot study conducted before performing the main study. The questionnaires tested on a sample of 20 nurses, and they excluded from the main study sample. The aim was to check the clarity, completeness and practicability of the survey tools, and time needed to fulfill the questionnaires.

\subsection{Field work}

Data collection was started from February 2014 to April 2014. Regarding the self-assessment questionnaires, the sheets were filled by the nurses through 15-20 minutes for each nurse.

\subsection{Administrative design}

An official permission was obtained using proper channels of communication. The total participants fulfilled an informed consent before giving any data or doing any investigations. The researcher explained the aim of the study in a straightforward manner to be understood by the ordinary people. No risky maneuvers were performed or used. Nurses $(n=200)$ were reassurance that their entire data considered confidential, through coding of their data, and not used outside this study without their approval. The researcher confirmed voluntary participation and withdrawal of the nurses without any rationale. Methods of communication with the investigator were identified to return at any time for any explanation.

\subsection{Statistical design}

To obtain a power of $90 \%$ with an assumption of $\alpha$ as 0.05 a sample size of 200 nurses required. The first (Study) group of nested case-control study included 147 nurses and the second (Control) group included 53 nurses. Data processing was done using Microsoft Excel software. Data were then imported and managed using Statistical Package for Social Sciences (SPSS) version 20 (IBM SPSS Ver. 20.0).

Quantitative or continuous data with normal distribution expressed primarily based on means and standard deviations (SD). Meanwhile, qualitative or categorical data presented as frequencies (numbers) and percentages. Pearson Correlation Coefficient test used to compute the correlation between two continuous variables. Meanwhile, Spearman Rho Correlation Coefficient test used to calculate the correlation between one ordinal (qualitative) and one continuous (quantitative) variables.

Two types of variables included in this research:

1) Independent/explanatory variables such as age, educational qualification, years of experience, attended training courses, and marital status.

2) Dependent/outcome variables such as interpersonal conflict, job satisfaction, and TEQ scores. Comparisons between two groups were made using t-test for continuous or quantitative data and chi-square $\left(\chi^{2}\right)$ test for categorical or qualitative data. Analysis of variance (ANOVA) test computed the comparison between more than two groups. The best fitting predictors of the study variables were evaluated using multivariate regression analysis models with backward elimination. $p$-value of less than or equal (.05) considered statistically significant.

\section{RESULT}

The results of the first-stage:

Table 1 showed the distribution of the studied nurses according to their demographic characteristics. The mean age of the studied population was $29.74 \pm 9.46$ years. The nurses recruited from the following departments/units: Internal Medicine (9.5\%), General Surgery (8.0\%), Pediatrics (11.0\%), Intensive Care Unit (ICU) (19.0\%), Obstetrics \& Gynecology (12.5\%), Emergency Unit (15.5\%), Major Operation (14.5\%), and Dialysis Unit (10.0\%). Approximately, $53 \%$ of the participants had nursing diplomate, $59.5 \%$ of them had $\geq 5$ years of experience in nursing practice and $43.5 \%$ of the nurses attended training courses. About, $54 \%$ of the studied nurses were married.

The majority of the studied nurses perceived themselves to have interpersonal conflicts $(n=147,73.5 \%)$ while only 
$26.5 \%(n=53)$ of them didn't have conflicts (see Table

2). This observation is matching the first hypothesis, which stated: "The nurses working at Ismailia General Hospital had a high incidence of interpersonal conflict."

Table 1. Distribution of the studied nurses according to their demographic characteristics $(n=200)$

\begin{tabular}{|c|c|}
\hline \multirow{2}{*}{ Variables } & Total population $(n=200)$ \\
\hline & No. (\%) \\
\hline \multicolumn{2}{|l|}{ Age (years) } \\
\hline $20-$ & 113 (56.5\%) \\
\hline $30-$ & $56(28.0 \%)$ \\
\hline $40-$ & $18(9.0 \%)$ \\
\hline$>50$ & $13(6.5 \%)$ \\
\hline Mean \pm SD & $29.74 \pm 9.46$ \\
\hline Range & $20-52$ \\
\hline \multicolumn{2}{|l|}{ Departments/units } \\
\hline Internal Medicine & 19 (9.5\%) \\
\hline General Surgery & $16(8.0 \%)$ \\
\hline Pediatrics & $22(11.0 \%)$ \\
\hline Intensive Care Unit & $38(19.0 \%)$ \\
\hline Obstetrics \& Gynecology & 25 (12.5\%) \\
\hline Emergency Unit & 31 (15.5\%) \\
\hline Major Operation & 29 (14.5\%) \\
\hline Dialysis Unit & $20(10.0 \%)$ \\
\hline \multicolumn{2}{|l|}{ Educational qualification } \\
\hline Health Technical Diplomate & 95 (47.5\%) \\
\hline Nursing School Diplomate & 105 (52.5\%) \\
\hline \multicolumn{2}{|l|}{ Years of experience } \\
\hline$<5$ years & 81 (40.5\%) \\
\hline 5-10 years & $60(30.0 \%)$ \\
\hline >10 years & 59 (29.5\%) \\
\hline Mean \pm SD & $8.9 \pm 7.7$ \\
\hline Range & $1-30$ \\
\hline \multicolumn{2}{|l|}{ Attended training courses } \\
\hline Yes & $87(43.5 \%)$ \\
\hline No & $113(56.5 \%)$ \\
\hline \multicolumn{2}{|l|}{ Marital Status } \\
\hline Unmarried & 93 (46.5\%) \\
\hline Married & 107 (53.5\%) \\
\hline
\end{tabular}

Note. Standard deviation (SD)

One-hundred fifty nurses (75\%) were dissatisfied with their job (29/200 and 121/200 had low and very low satisfactory levels, respectively). Forty-two nurses (21\%) had average satisfaction and only eight nurses (4\%) had high to very high job satisfaction (6/200 and 2/200 of high and very high satisfactory level). Regarding team effectiveness, more than half $(57.5 \%)$ of the nursing staff reported low team effectiveness while $42.5 \%$ of them reported high level of team effectiveness, as shown in Table 2.

Table 2. Distribution of the studied nurses according to interpersonal conflict, job satisfaction, and team effectiveness $(n=200)$

\begin{tabular}{ll}
\hline Variables & Total population (n= 200) \\
\cline { 2 - 2 } & No. $(\%)$ \\
\hline Interpersonal conflict & $147(73.5 \%)$ \\
Present $(\geq 60 \%)$ & $53(26.5 \%)$ \\
Absent $(<60 \%)$ & $55.2 \pm 7.5$ \\
Mean \pm SD & $23-67$ \\
Range & \\
Job satisfaction & $150(75.0 \%)$ \\
Dissatisfied & $29(14.5 \%)$ \\
Very low satisfactory level & $121(60.5 \%)$ \\
Low satisfactory level & $50(25.0 \%)$ \\
Satisfied & $42(21.0 \%)$ \\
Average satisfactory level & $6(3.0 \%)$ \\
High satisfactory level & $2(1.0 \%)$ \\
Very high satisfactory level & $25.5 \pm 8.2$ \\
Mean \pm SD & $10-43$ \\
Range & \\
Team effectiveness & $85(42.5 \%)$ \\
High $(\geq 60 \%)$ & $115(57.5 \%)$ \\
Low ( $<60 \%)$ & $29.8 \pm 5.0$ \\
Mean \pm SD & $18-40$ \\
Range & \\
\hline
\end{tabular}

Note. Standard deviation (SD)

From all eight dimensions of team effectiveness scores, the highest one was skills \& learning with mean of $4.11 \pm 1.08$ followed by team processes $(4.10 \pm 1.02)$ and the lowest one was Purpose \& goals with a mean of $3.14 \pm 1.56$.

There were insignificant differences between nurses who working in ICU and who working in wards regarding interpersonal conflict (65.8\% versus $72.0 \%$, respectively) and job dissatisfaction (68.4\% versus $73.2 \%$, respectively) $(p>.05)$.

Regarding correlations between variables, there were significant negative correlations between interpersonal conflict scores and age, marital status, and years of experience $(p<$ .01 ), while, these explanatory variables positively correlated with job satisfaction and total team effectiveness scores $(p<$ .01) (see Table 3).

The present study revealed that there were significant negative correlations between interpersonal conflict, and job satisfaction $(r=-0.303, p<.0001)$, and team effectiveness 
$(r=-0.201, p=.004)$ scores (see Table 3, Figure 1). Mean- job satisfaction and team effectiveness scores $(r=-0.283, p$ while, there were significant positive correlations between <.0001) (see Table 3).

Table 3. Correlations between interpersonal conflict, job satisfaction and team effectiveness among the studied nurses $(\mathrm{n}=$ 200)

\begin{tabular}{|c|c|c|c|c|c|c|}
\hline & \multicolumn{2}{|c|}{ Interpersonal conflict scores } & \multicolumn{2}{|c|}{ Job satisfaction scores } & \multicolumn{2}{|c|}{ Team effectiveness scores } \\
\hline & $r$ & $p$-value & $r$ & $p$-value & $r$ & $p$-value \\
\hline \multicolumn{7}{|l|}{ Explanatory variables } \\
\hline Age & -.574 & $<.0001^{* *}$ & .395 & $<.0001^{* *}$ & .358 & $<.0001^{* *}$ \\
\hline Marital status & -.414 & $<.0001^{* *}$ & .230 & $.001^{* *}$ & .336 & $<.0001^{* *}$ \\
\hline Qualification & .010 & 0.886 & .037 & .598 & .094 & .185 \\
\hline Experience & -.609 & $<.0001^{* *}$ & .359 & $<.0001^{* *}$ & .278 & $<.0001^{* *}$ \\
\hline \multicolumn{7}{|l|}{ Outcome variables } \\
\hline Interpersonal conflict scores & 1 & - & -.303 & $<.0001^{* *}$ & -.201 & $.004 * *$ \\
\hline Job satisfaction scores & -.303 & $<.0001^{* *}$ & 1 & - & .283 & $<.0001 * *$ \\
\hline Team effectiveness scores & -.201 & $.004 * *$ & .283 & $<.0001^{* *}$ & 1 & - \\
\hline \multicolumn{7}{|c|}{ Team effectiveness dimensions } \\
\hline Purpose \& goals & -.056 & .431 & .120 & .089 & .579 & $<.0001^{* *}$ \\
\hline Roles & -.019 & .789 & .019 & .791 & .362 & $<.0001^{* *}$ \\
\hline Team processes & -.131 & .065 & .193 & $.006 * *$ & .392 & $<.0001 * *$ \\
\hline Team relationships & -.106 & .136 & .113 & .112 & .463 & $<.0001^{* *}$ \\
\hline Intergroup relations & -.164 & $.020 *$ & .184 & $.009 * *$ & .614 & $<.0001^{* *}$ \\
\hline Problem solving & -.056 & .428 & .134 & .058 & $.448^{* *}$ & $<.0001^{* *}$ \\
\hline Cohesion & -.188 & $.008 * *$ & .252 & $<.0001^{* *}$ & $.566^{* *}$ & $<.0001^{* *}$ \\
\hline Skills \& learning & -.043 & .549 & .052 & .467 & $.352^{* *}$ & $<.0001^{* *}$ \\
\hline
\end{tabular}

*Significant $p<.05, * *$ Highly significant $p<.01$

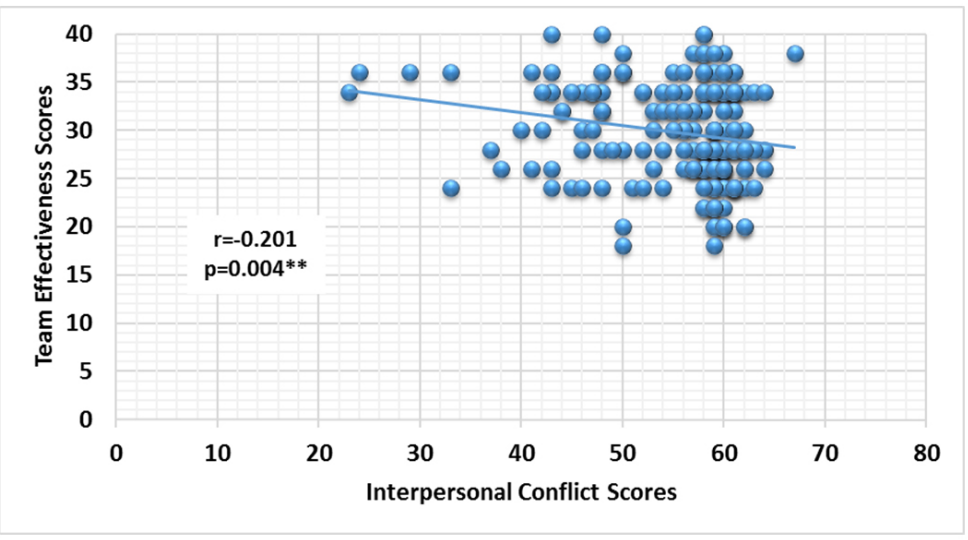

Figure 1. Scatterplot chart is demonstrating the significant negative correlation between interpersonal conflict and team effectiveness among surveyed nurses $(\mathrm{n}=200)$

The small balls represent all nursing scores of the two variables; interpersonal conflict (on horizontal axis) and team effectiveness (on vertical axis)

These findings established the second, the third and the fourth hypotheses, which stated: Hypothesis 2: "There is a significant negative correlation between interpersonal conflict and job satisfaction", Hypothesis 3: "There is a significant neg- ative correlation between interpersonal conflict and team effectiveness", and Hypothesis 4: "There is a significant positive correlation between job satisfaction and team effectiveness". 
Also, intergroup relations and cohesion dimensions of TEQ were negatively correlated with interpersonal conflict scores $(p<.05)$. In contrast, team processes, intergroup relations, and cohesion subscales of TEQ positively correlated with job satisfaction scores $(p<.05)$.
Figure 2 showed that the mean conflict score in nurses with a minimal degree of job satisfaction was significantly higher than in nurses with average, high and very high satisfaction (57.0 versus 50.9, 53.8 and 50.5, respectively) $(p<.0001)$.

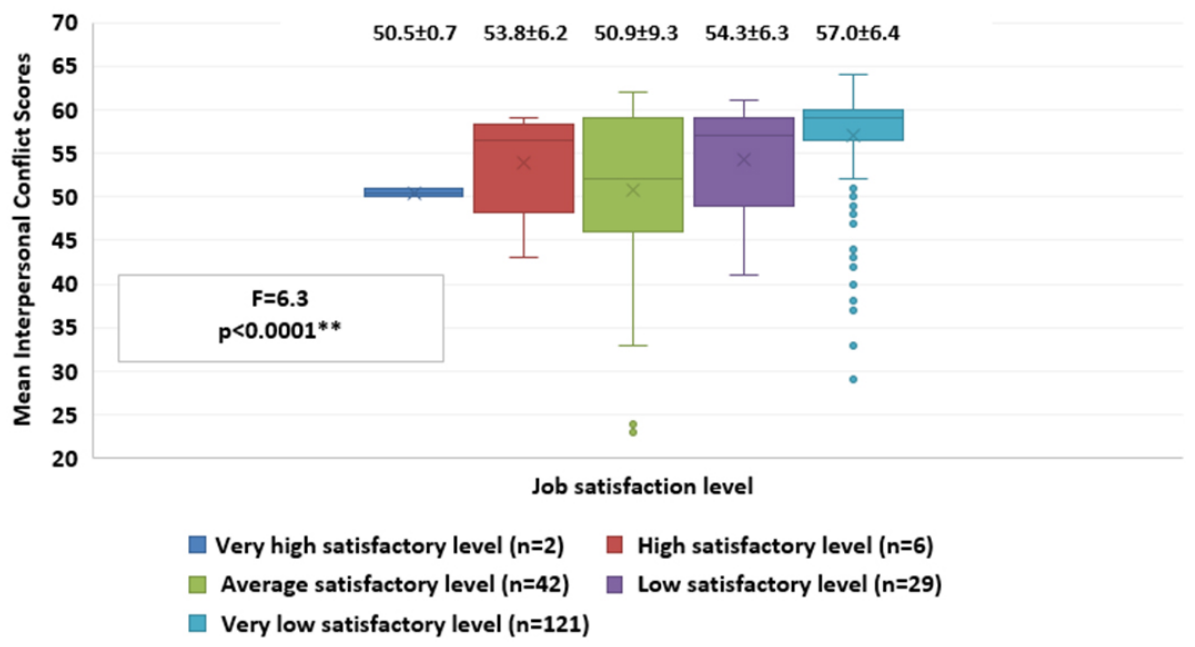

Figure 2. Box-Whisker-plot chart is demonstrating the link between the degree of job satisfaction and the mean scores of interpersonal conflict questionnaire

The horizontal line dividing the box is the mean. The whiskers represent the lowest and highest range (minimum and maximum), while outlying data are shown as small circles

Figure 3 demonstrated the mean scores of team effective- level of job satisfaction, the higher the mean scores of team ness dimensions in relation to the level of job satisfaction of effectiveness dimensions. the studied nurses. The chart indicated that the higher the

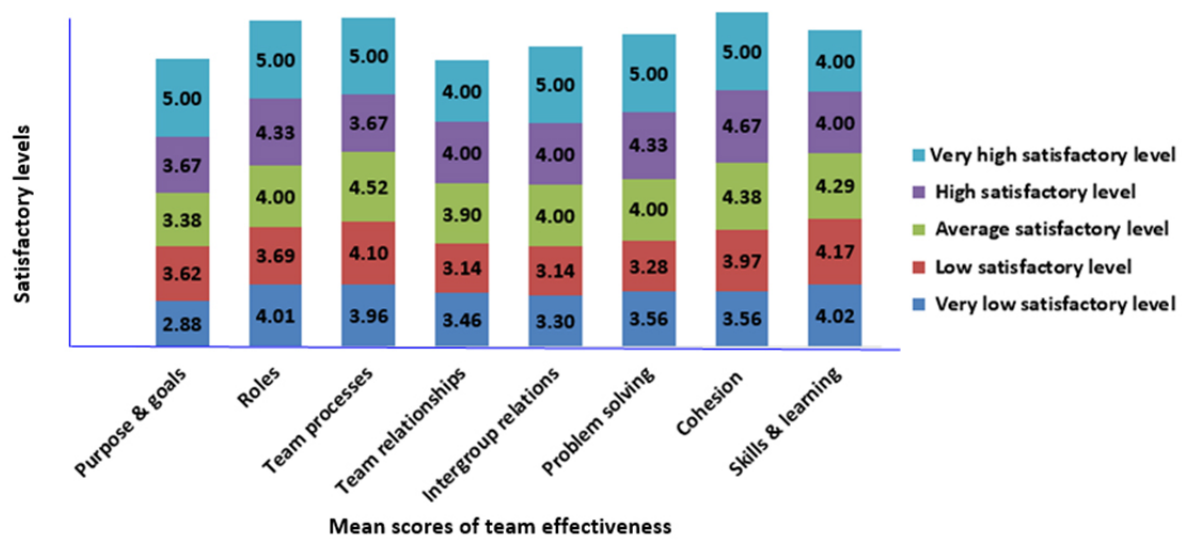

Figure 3. Mean scores of team effectiveness dimensions in relation to the level of job satisfaction of the studied nurses

The results of the second-stage:

Table 4 showed the comparison between demographic data, job satisfaction, and team effectiveness among the study and the control groups. The nurses with interpersonal conflict (study group) were younger-aged (average 25.95 years), single $(61.2 \%)$ with limited experience (average six years). Meanwhile, the nurses without interpersonal conflict (con- trol group) were older-aged (average 40.26 years), married $(94.3 \%)$ with high experience (average 17.69 years). There were significant differences between study and control groups regarding age, marital status, and experience ( $p$ $<.05)$. So, the fifth, the sixth and the seventh hypotheses was accepted, which stated that: Hypothesis 5: "There are significant differences between the nurses with interpersonal 
conflict and the nurses without interpersonal conflict regard- satisfaction scores", and Hypothesis 7: "There are significant ing demographic data", Hypothesis 6: "There are significant differences between the nurses with interpersonal conflict and the nurses without interpersonal conflict regarding job differences between the nurses with interpersonal conflict and the nurses without interpersonal conflict regarding team effectiveness scores".

Table 4. Demographic characteristics among study and control groups

\begin{tabular}{|c|c|c|c|c|}
\hline Variables & Study group $(\mathrm{n}=147)$ & Control group $(n=53)$ & Used test & $p$-value \\
\hline \multicolumn{5}{|c|}{ Independent/explanatory variables } \\
\hline \multicolumn{5}{|l|}{ Age (years) } \\
\hline Mean \pm SD & $25.95 \pm 6.36$ & $40.26 \pm 8.72$ & $t=12.7$ & $<.0001 * *$ \\
\hline \multicolumn{5}{|l|}{ Educational qualification } \\
\hline Health Technical Diplomate & $75(51.0 \%)$ & $20(37.7 \%)$ & & \\
\hline Nursing School Diplomate & $72(49.0 \%)$ & $33(62.3 \%)$ & $\chi^{2}=2.8$ & .10 \\
\hline \multicolumn{5}{|l|}{ Years of experience } \\
\hline Mean \pm SD & $6.00 \pm 4.38$ & $17.69 \pm 7.95$ & $t=13.2$ & $<.0001 * *$ \\
\hline \multicolumn{5}{|l|}{ Marital Status } \\
\hline Unmarried & $90(61.2 \%)$ & $3(5.7 \%)$ & & \\
\hline Married & $57(38.8 \%)$ & $50(94.3 \%)$ & $\chi^{2}=48.3$ & $<.0001 * *$ \\
\hline \multicolumn{5}{|l|}{ Job satisfaction } \\
\hline Dissatisfied $(\mathrm{n}=150)$ & $123(83.7 \%)$ & $27(50.9 \%)$ & $\chi^{2}=22.2$ & $<.0001^{* *}$ \\
\hline Satisfied $(\mathrm{n}=50)$ & $24(16.3 \%)$ & $26(49.1 \%)$ & & \\
\hline Mean \pm SD & $23.63 \pm 7.72$ & $30.51 \pm 7.47$ & $t=5.6$ & $<.0001^{* *}$ \\
\hline \multicolumn{5}{|l|}{ Dependent/outcome variables } \\
\hline \multicolumn{5}{|l|}{ Team effectiveness } \\
\hline $\operatorname{High}(\mathrm{n}=85)$ & $53(36.1 \%)$ & $32(60.4 \%)$ & $\chi^{2}=9.4$ & $.002 * *$ \\
\hline Low $(\mathrm{n}=115)$ & $94(63.9 \%)$ & $21(39.6 \%)$ & & \\
\hline Mean \pm SD & $29.24 \pm 4.97$ & $31.36 \pm 4.94$ & $t=2.7$ & $.009 * *$ \\
\hline \multicolumn{5}{|l|}{ Team effectiveness dimensions } \\
\hline Purpose \& goals & $3.05 \pm 1.55$ & $3.48 \pm 1.57$ & $t=1.70$ & .08 \\
\hline Roles & $4.01 \pm 1.08$ & $3.91 \pm 1.15$ & $t=0.57$ & .57 \\
\hline Team processes & $4.02 \pm 1.03$ & $4.32 \pm 0.96$ & $t=1.91$ & .07 \\
\hline Team relationships & $3.46 \pm 1.24$ & $3.72 \pm 1.31$ & $t=1.69$ & .08 \\
\hline Intergroup relations & $3.33 \pm 1.62$ & $3.83 \pm 1.49$ & $t=2.00$ & $.05^{*}$ \\
\hline Problem solving & $3.57 \pm 1.48$ & $3.87 \pm 1.33$ & $t=1.30$ & .20 \\
\hline Cohesion & $3.71 \pm 1.34$ & $4.21 \pm 1.20$ & $t=2.39$ & $.018^{*}$ \\
\hline Skills \& learning & $4.09 \pm 1.10$ & $4.13 \pm 1.00$ & $t=0.23$ & .82 \\
\hline
\end{tabular}

*Significant $p<.05, * *$ highly significant $p<.01, t=t$-test, $\chi^{2}=$ chi-square test.

Regarding job satisfaction, the percentage of dissatisfied nurses in the study group (83.7\%) was significantly higher than the percentage of dissatisfied nurses in the control group $(50.9 \%)$. Also, the mean scores of job satisfaction scale were significantly lower among the study group compared to the control group. Regarding team effectiveness, the percentage of nurses with low effectiveness score in the study group (63.9\%) was significantly more than the percentage of nurses with low effectiveness score in the control group (39.6\%).
In addition, the study group had significantly lower mean score of TEQ compared to the control group $(29.24 \pm 4.97$ versus $31.35 \pm 4.94$, respectively) $(p=.008)$. Also, the mean scores of intergroup relations and cohesion dimensions of TEQ were significantly lower among the study group in comparison to the control group $(p<.05)$ (see Table 4).

Using multivariate regression analysis models, age $(\beta=$ $-0.26, p=.02)$, experience $(\beta=-0.41, p<.0001)$, and job satisfaction $(\beta=-0.12, p=.029)$ were significant negative 
predictors of interpersonal conflict. Team effectiveness was not a significant predictor of interpersonal conflict. This partially fulfills our eighth hypothesis, which stated that: Hypothesis 8: "Demographic characteristics, job satisfaction, and team effectiveness are significant predictors of interpersonal conflict".
Age $(\beta=.19, p=.035)$ and team effectiveness $(\beta=-0.18, p$ $=.011)$ were significant positive predictors of job satisfaction while interpersonal conflicts $(\beta=-0.21, p=.016)$ was an important negative predictor. Age $(\beta=0.27, p<.0001)$ and job satisfaction $(\beta=0.22, p=.002)$ were significant positive predictors of team effectiveness (see Table 5).

Table 5. Significant predictors of the outcome variables (interpersonal conflict, job satisfaction, and team effectiveness) using multivariate regression analysis model with backward elimination

\begin{tabular}{|c|c|c|c|c|}
\hline \multirow{2}{*}{ Variables } & \multicolumn{2}{|c|}{ Coefficients } & \multirow{2}{*}{ Used test } & \multirow{2}{*}{$p$-value } \\
\hline & B & Beta & & \\
\hline \multicolumn{5}{|l|}{ Interpersonal conflicts } \\
\hline Age & -0.012 & -0.259 & -2.351 & $.020^{*}$ \\
\hline Experience & -0.023 & -0.410 & -3.781 & $<.0001^{* *}$ \\
\hline Job satisfaction & -0.007 & -0.121 & -2.197 & $.029 *$ \\
\hline ANOVA & & & $F=64.7$ & $<.0001^{* *}$ \\
\hline \multicolumn{5}{|l|}{ Job satisfaction } \\
\hline Age & 0.167 & 0.192 & $t=2.119$ & $.035^{*}$ \\
\hline Interpersonal conflicts & -3.893 & -0.209 & $t=-2.434$ & $.016 *$ \\
\hline Team effectiveness & 0.285 & 0.175 & $t=2.551$ & $.011 *$ \\
\hline ANOVA & & & $F=16.6$ & $<.0001^{* *}$ \\
\hline \multicolumn{5}{|l|}{ Team effectiveness } \\
\hline Age & 0.143 & 0.269 & 3.797 & $<.0001^{* *}$ \\
\hline Job satisfaction & 1.169 & 0.224 & 3.171 & $.002 * *$ \\
\hline ANOVA & & & $F=20.3$ & $<.0001^{* *}$ \\
\hline
\end{tabular}

Note. Analysis of variance (ANOVA)

\section{Discussion}

Conflict is inevitable in professional nursing life. ${ }^{[40,41]} \mathrm{Un}$ resolved conflict among nurses is a major issue resulting in job dissatisfaction, negative emotions and turnover intentions. ${ }^{[12-15]}$ Conflict can lead to adverse impact on both the individual and the organization. ${ }^{[5]}$

The present study aimed to estimate the incidence of interpersonal conflict among nurses. The frequency was high where, the majority of the surveyed nurses had interpersonal conflicts (73.5\%), which fulfill the first hypothesis. This considerably high incidence of interpersonal conflict among staff nurses in the hospital setting may arise from complicated and frequent interactions between the nurses and other staff members, where various perspectives can lead to conflicts. ${ }^{[42]}$

In a similar direction, an Egyptian author, Higazee, ${ }^{[11]}$ determined the level of conflict perceived by hospital nurses. He observed that the majority of the studied nurses $(72.7 \%)$ have moderate to high level of conflict. In Saudi Arabian study, Zakari et al. ${ }^{[43]}$ reported that $82.1 \%$ of the included nurses had interpersonal conflict. Moreover, Kunaviktikul and his colleagues $^{[44]}$ assessed in their study the level of conflict, the level of job satisfaction, and turnover intention among nurses. The study observed that staff nurses had a moderate degree of conflict.

The present study identified the correlations between interpersonal conflict, job satisfaction and team effectiveness among staff nurses. Interpersonal conflict scores among the surveyed nurses negatively correlated with their age. The nurses with interpersonal conflict were younger-aged, single with minimal experience compared to the nurses without conflict who were more expert older-aged individuals.

Regarding these age differences, the study performed by Havenga ${ }^{[45]}$ revealed that there was a significant statistical difference between the different age groups regarding handling with interpersonal conflict. Parallel to our study regarding lower conflict among expert older-aged individuals, Gökçe et al. ${ }^{[46]}$ found that the experienced staff having an age of more than 40 years had higher job performance and lower interpersonal conflict than younger-aged staff.

On the other hand, we concluded that inexperienced nurse had higher interpersonal conflict and job dissatisfaction level, 
these finding were supported by Mulki et al. ${ }^{[47]}$ who stated that experience has a negative relationship with stress and conflict.

These findings can be interpreted as experienced individuals are less vulnerable to the adverse effects of stress and conflict factors such as panic from making mistakes, anxiety of career pathway, work overload or job security. As a result, it can be suggested that promoting the emotional regulation could decrease the negative effects of job stress and interpersonal conflict. Educational abilities have positive effects on emotional regulation and job performance; and negative effect on interpersonal conflict. ${ }^{[46]}$

The study showed a significant negative correlation between interpersonal conflict scores and marital status $(p<.01)$, where $61.2 \%$ of the nurses with interpersonal conflict were unmarried. This finding may be because they are younger and assigned more tasks than their older and senior colleagues. Furthermore, married nurses often take maternity leave that gives them a break and let them rest in their homes regaining their power and recovering from the stressful events associated with the working climate. In this regards, Okwaraji and $\mathrm{En}^{[48]}$ observed high burnout and pschological distress levels among unmarried nurses compared to married nurses.

Furthermore, Adekola ${ }^{[49]}$ found that family life strengthens the emotional wellbeing, human contacts, and interpersonal communications. He also reported that married females with helpful husbands who share them the housework and family responsibilities and support their career development are less susceptible to conflict and have a lower frequency of burnout compared to unmarried females who don't have such support and assistance.

The first-stage study showed that there were significant negative correlations between interpersonal conflict, and job satisfaction and team effectiveness. Meanwhile, there were significant positive correlations between job satisfaction and team effectiveness. These observations emphasized by the second-stage study, which comparing the mean scores of job satisfaction scale and TEQ in the study group (nurses with interpersonal conflict) versus the control group (nurses without conflict). The study group showed signifcantly lower mean scores of job satisfaction and team effectiveness compared to the control group. These findings emphasized the direct correlations between interpersonal conflict and job outcomes. ${ }^{[10]}$ The present observations were supported by Jaramillo et al., ${ }^{[50]}$ who found a significant link between interpersonal conflict, workplace stressors, job attitude, job behaviors, and job satisfaction.

Several studies in Arabic and Islamic countries were consis- tent with our findings. In one Jordanian study, Mohammad et al. ${ }^{[1]}$ found that reduced levels of distress and conflict has a positive correlation with job satisfaction in nurses working in private hospitals. In another Jordanian study, AbuAlrub and $\mathrm{Al}-\mathrm{Zaru}^{[52]}$ study conducted in four governmental hospitals revealed that job stress with lower job satisfaction exaggerate interpersonal conflict and increased the nurses' intention to leave employment. It was recommended to set clear strategies to be able recognize nurses' achievements, enhance motivation and reward high performance with continued feedback so as to encourage team effectiveness. In Pakistani study, Mansoor et al. ${ }^{[53]}$ found that job stress such as conflicts with supervisors, conflicts with colleagues, conflicts with subordinates and conflicts with management policies were negatively correlated with job satisfaction. They concluded that individuals with excessive stress tend to become dissatisfied with their jobs. In another Pakistani study, Bashir and Ramay ${ }^{[54]}$ added that job dissatisfaction may result from several factors including high interpersonal conflict, weak team effectiveness, little work data, continuously progressive changes of job environment, or minimum individual cope with job requirements. In Malaysian study, Ahsan et al. ${ }^{[5]}$ also observed this significant negative impact of conflict on job satisfaction. In one Turkish study, Gökçe et al. ${ }^{[46]}$ determined that there was significant positive linear correlation between job stress and interpersonal conflict. In another two Turkish studies, Yozgat et al. ${ }^{[56]}$ and Nadinloyia et al. ${ }^{[57]}$ stated that job stress and conflict have negative effects on job performance and satisfaction.

The study performed by Bernhard and O'Driscoll ${ }^{[58]}$ identified the correlations between work-related conflict, burnout, job dissatisfaction, and low general health of nurses. They stated that low level of interpersonal conflict among staff nurses might be due to work with the same team for a long time, which lead to more trust, agreement of thoughts and a higher level of team effectiveness.

In Jordan, Mrayyan ${ }^{[59]}$ in (2009) examined the job satisfaction and stressors for 228 nurses working in ICU. The job stress for nurses working in the ICU was higher than those working inwards and the main job stressors, and dissatisfactory factors were: conflict with physicians and lack of team support. Our study didn't find significant differences between nurses who working in ICU and who working inwards regarding interpersonal conflict and job dissatisfaction $(p>.05)$. The difference between our study and Mrayyan ${ }^{[59]}$ study may be because the main objective of Mrayyan ${ }^{[59]}$ study is to explore the differences between ICU and wards regarding job stressors, meanwhile, this wasn't our aim. Also, may be due to the higher sample of nurses who are working in ICU in his study compared to our sample (228 nurses 
versus 38 nurses, respectively).

Similarly, Jaramillo et al. ${ }^{[50]}$ provided insights into the interpersonal relations inside the organization and the coworkers. They detected that conflict inside work groups can range from private job behaviors and dissatisfaction up to the physical harm.

About the causes of conflict and job dissatisfaction, Rao and Borkar $^{[60]}$ believed that individuals with hesitated abilities, insufficient knowledge, and little practice opposite to operational needs would end in a higher incidence of interpersonal conflict and job dissatisfaction.

Job satisfaction is one of the primary outcome (study) which is variable in our study. The majority of the surveyed nurses $(75 \%)$ had low and very low scores of job satisfaction or dissatisfied as we classified them. This obsevation occurred because they suffered from the unavailability of sufficient resources that in turn affect the work goals, plans, cooperation, and decisions. The researcher attributed that the studied sample belonged to the Egyptian society with unresolved issues of human and material resources.

Our data revealed that there were significant positive correlations between job satisfaction and team effectiveness. Regression analysis models emphasized these associations. Age and team effectiveness were significant positive predictors of job satisfaction while interpersonal conflicts were significant negative one.

Job satisfaction is one of the output (outcome) of the inputprocess-output model. The model assesses the influence of input (e.g. team composition) and the mediating process (e.g. conflict) on team output (e.g. team performance and job satisfaction). ${ }^{[23,61-63]}$ Team effectiveness expressed by this model in many types of research. Several studies have shown that team effectiveness significantly predicts job satisfaction. ${ }^{[17,64-66]}$

This study assessed the depth of the relationship between job satisfaction and team effectiveness dimensions and it indicated that the higher the level of job satisfaction, the higher the mean scores of the team effectiveness dimensions and vice versa.

Many studies identified the impact of effective team on sev- eral outcome levels including patients' level, nursing staff level, and institutional level. On the patient's level, team effectiveness is correlated with higher satisfaction and treatment acceptance. On the staff's level, the researchers reported that the larger the team effectiveness, the greater job satisfaction, and the more team environment improvement. On the institutional level, effective team is associated with higher workforce preservation and decreased turnover. ${ }^{\text {[67-71] }}$

The increase of organizational awareness about the importance of job satisfaction and team effectiveness of the nursing staff is a critical issue. Our study results revealed the importance of evaluating the incidence and effects of interpersonal conflict on job satisfaction of the staff nurses. Also, the study unmasks the close relationship and bidirectional association between job satisfaction and team effectiveness.

\section{Conclusions}

The conclusions of the first-stage study pointed out that the incidence of interpersonal conflict among nurses was very high. Moreover, the interpersonal conflict negatively correlated with job satisfaction and team effectiveness while job satisfaction positively correlated with team effectiveness. Meanwhile, the second-stage study showed that there were significant differences between study and control groups regarding demographic data, job satisfaction, and team effectiveness scores. In addition, age, experience, and job satisfaction were significant negative predictors of interpersonal conflict.

\section{RECOMMENDATIONS}

In the light of the study results the following are recommended: Designing and implementing an educational program on "different conflict management styles" and "how to manage interpersonal conflict". Future research in this area is necessary with a larger sample ranging across different governmental and private hospitals in various governorates to enhance our understanding of the primary causes of conflict and to investigate its correlation with job satisfaction and team effectiveness of the nursing staff.

\section{CONFLICTS OF INTEREST Disclosure}

The author declares that there is no conflict of interests.

\section{REFERENCES}

[1] West MA, Markiewicz L. Building Team-Based Working. BPS Blackwell, Oxford; 2004. http://dx.doi.org/10.1002/978047077 4700

Published by Sciedu Press
[2] Speakman J, Ryals L. A re-evaluation of conflict theory for the management of multiple, simultaneous conflict episodes. Inter J Confl Manag. 2010 Apr 27; 21(2): 186-201. http://dx.doi.org/10. $1108 / 10444061011037404$ 
[3] Aghdasi S, Kiamanesh AR, Ebrahim AN. Emotional Intelligence and organizational commitment: testing the mediatory role of occupational stress and job satisfaction. Proced Soc Behav Sci. 2011 Dec 31; 29: 1965-76. http://dx.doi.org/10.1016/j.sbspro.2011.1 1.447

[4] Sullivan EJ, Decker PJ. Effective leadership and management in nursing (7th ed.). Upper Saddle River, N.J: Pearson Prentice Hall; 2009. $156 \mathrm{p}$.

[5] Hurt KJ, Abebe MA. The Effect of Conflict Type and Organizational Crisis on Perceived Strategic Decision Effectiveness an Empirical Investigation. J Leadersh Organ Stud. 2015 Aug 1; 22(3): 340-54. http://dx.doi.org/10.1177/1548051815570038

[6] Montana PJ, Charnov BH. Management. New York, Barron's Educational Series Inc.; 2008. 333 p.

[7] Gulati R, Mayo A, Nohria N. Management (1st ed). Cengage Learning; 2014. 411-7 p.

[8] West M, Dawson J, Admasachew L, et al. NHS staff management and health service quality. London: Department of Health; 2011.

[9] DuBrin AJ. Applying psychology: Individual and organizational effectiveness. Prentice Hall; 2004.

[10] Mahdian MJ, Yari M. The Relationship between Interpersonal Conflict and Job Outcomes: Exposition of the Mediating Role of Perception of Organizational Politics. J Appl Environ Biol Sci. 2014; 4(4): 223-30.

[11] Higazee MZ. Types and Levels of Conflicts Experienced by Nurses in the Hospital Settings. Health Sci J. 2015.

[12] Spector PE. A control theory of the job stress process. Theories of organizational stress. 1998 Oct 29: 153-69.

[13] Frone MR. Interpersonal conflict at work and psychological outcomes: testing a model among young workers. J Occup Health Psychol. 2000 Apr; 5(2): 246. PMid:10784288 http://dx.doi.org /10.1037/1076-8998.5.2.246

[14] Giebels E, Janssen O. Conflict stress and reduced well-being at work: The buffering effect of third-party help. Eur J Work Organ Psychol 2005 Jun 1; 14(2): 137-55. http://dx.doi.org/10.1080/135 94320444000236

[15] Spector PE, Bruk-Lee V. Conflict, health, and well-being. The psychology of conflict and conflict management in organizations San Francisco: Jossey-Bass. [SIOP Frontier Series]. 2008: 267.

[16] Demsky CA. Interpersonal conflict and employee well-being: The moderating role of recovery experiences. [Dissertations and Theses]. Portland State University; 2012.

[17] Kalisch BJ, Lee H, Rochman M. Nursing staff teamwork and job satisfaction. J Nurs Manag. 2010 Nov 1; 18(8): 938-47. PMid:21073567 http://dx.doi.org/10.1111/j.1365-2834.2010.01153.x

[18] Baggs JG, Schmitt MH, Mushlin AI, et al. Association between nurse-physician collaboration and patient outcomes in three intensive care units. Crit Care Med. 1999 Sep; 27(9): 1991-8. PMid:10507630 http://dx.doi.org/10.1097/00003246-199909000-00045

[19] Griffin MA, Patterson MG, West MA. Job satisfaction and teamwork: The role of supervisor support. Journal of Organizational Behavior 2001 Aug 1; 22(5): 537-50. http://dx.doi.org/10.1002/job .101

[20] Heywood JS, Jirjahn U. Teams, teamwork and absence. Scand J Econ. 2004 Dec 1; 106(4): 765-82. http://dx.doi.org/10.1111/j.0 347-0520.2004.00387.x

[21] Borrill C, West M, Shapiro D, et al. Team working and effectiveness in health care. Br J Healthc Manag. 2000; 6(8): 364-71.

[22] Rafferty AM, Ball J, Aiken LH. Are teamwork and professional autonomy compatible, and do they result in improved hospital care? Qual Health Care. 2001 Dec 1; 10(suppl 2): ii32-7. http: //dx.doi.org/10.1136/qhc.0100032
[23] Xyrichis A, Ream E. Teamwork: a concept analysis. J Adv Nurs 2008 Jan 1; 61(2): 232-41. PMid:18186914 http://dx.doi.org /10.1111/j.1365-2648.2007.04496.x

[24] Borrill CS, Carletta J, Carter A, et al. The effectiveness of health care teams in the National Health Service. Birmingham: University of Aston in Birmingham; 2000 Mar.

[25] Al-Khasawneh AL, Moh S. The relationship between job stress and nurses' performance in the Jordanian hospitals: A case study in King Abdullah the Founder Hospital. Asian J Bus Manag. 2013 Apr 15; 5(2): 267-75.

[26] Hamaideh SH. Burnout, social support, and job satisfaction among Jordanian mental health nurses. Issue Ment Health Nurs. 2011 Mar 2; 32(4): 234-42. PMid:21355758 http://dx.doi.org/10.3109 /01612840.2010.546494

[27] Procter S, Currie G. Target-based team working: Groups, work and interdependence in the UK civil service. Human Relations. 2004 Dec 1; 57(12): 1547-72. http://dx.doi.org/10.1177/001872670 4049989

[28] Kane G, Labianca G. Accounting for clergy's social ledgers: Mixed blessings associated with direct and indirect negative ties in a religious organization. In Intra-Organizational Network (ION) Conference, Atlanta; 2005.

[29] Gelens A, de Jong JP. The impact of negative relationships on team functioning: from a conceptual approach towards a more pragmatic view. [Dissertations and Theses]. Master Thesis Organization Studies, Tilburg University, ANR S350412; 2011.

[30] Kelly P. Nursing Leadership \& Management (3rd ed.). Cengage Learning; 2012. pp. 312-20.

[31] Tse HM, Dasborough MT. A study of emotion and exchange in team member relationships. Gr Organ Manag. 2008; 33: 194-215. http://dx.doi.org/10.1177/1059601106293779

[32] De Dreu CKW, Van Vianen AEM. Managing relationship conflict and the effectiveness of organizational teams. J Organ Behav. 2001; 22: 309-28. http://dx.doi.org/10.1002/job.71

[33] De Dreu CKW, Weingart LR. Task versus relationship conflict, team performance, and team member satisfaction: a meta-analysis. J Appl Psychol. 2003; 8: 741-9. http://dx.doi.org/10.1037/0021-9 010.88 .4 .741

[34] Simons TL, Peterson RS. Task conflict and relationship conflict in top management teams: the pivotal role of intragroup trust. J Appl Psychol. 2000 Feb; 85(1): 102. PMid:10740960 http: //dx.doi.org/10.1037/0021-9010.85.1.102

[35] Cai T, Zheng Y. Evaluating prognostic accuracy of biomarkers in nested case-control studies. Biostatistics. 2011 Aug 19: kxr021.

[36] Shetewy JA. Conflict among Staff Nurse: Resolution Techniques and Relation to Leadership Styles, 2005.

[37] Macdonald S, MacIntyre P. The generic job satisfaction scale: scale development and its correlates. Empl Assist Quart. 1997; 13(2): 1e16.

[38] National Health Service (NHS). London Leadership Academy. Team effectiveness questionnaire. NHS, 2014. Available from: http://www. londonleadingforhealth.nhs.uk/sites/de fault/files/Team_effectiveness_diagnostic-LAL1.pdf

[39] Dunn OJ, Clark VA. Basic statistics: a primer for the biomedical sciences. John Wiley \& Sons Inc., Publication; 2009 Aug 11. p. 36-45.

[40] Al-Hamdan Z, Shukri R, Anthony D. Conflict management styles used by nurse managers in the Sultanate of Oman. Journal of Clinical Nursing. 2011 Feb 1; 20(3-4): 571-80. PMid:21219529 http://dx.doi.org/10.1111/j.1365-2702.2010.03557.x

[41] Al-Hamdan Z, Norrie P, Anthony D. Conflict management styles used by nurses in Jordan. J Res Nurs. 2014; 19(1): 4053. http: //dx.doi.org/10.1177/1744987112466085 
[42] Kleinman CS: Leadership strategies in reducing staff nurse role conflict. JONA. 2004, 34: 322-324. http://dx. doi . org/10 .1097/0 0005110-200407000-00003

[43] Zakari NM, Al Khamis NI, Hamadi HY. Conflict and professionalism: perceptions among nurses in Saudi Arabia. Int Nurs Rev. 2010 Sep; 57(3): 297-304. PMid:20796058 http://dx.doi.org/10.1111 /j.1466-7657.2009.00764.x

[44] Kunaviktikul W, Nuntasupawat R, Srisuphan W, et al. Relationships among conflict, conflict management, job satisfaction, intent to stay, and turnover of professional nurses in Thailand. Nurs Health Sci. 2000 Mar 1; 2(1): 9-16. http://dx.doi.org/10.1046/j.144 2-2018.2000.00033.x

[45] Havenga W. Gender and age differences in conflict management within small businessess. SA J Human Resour Manag. 2008 Oct 24; 6(1): 22-8. http://dx.doi.org/10.4102/sajhrm.v6i1.143

[46] Gökçe SG, Emhan A, Topuz G, et al. The Analysis of the Relationship between Job Stress, Interpersonal Conflict, Emotion Regulation Ability and Performance: A Research in the Automotive Sector. Inter J Bus Soc Sci. 2015 Aug; 8(1): 201-8.

[47] Mulki JP, Jaramillo F, Goad EA, et al. Regulation of emotions, interpersonal conflict, and job performance for salespeople. J Bus Res. 2015 Mar 31; 68(3): 623-30. http://dx.doi.org/10.1016/j.j busres.2014.08.009

[48] Okwaraji FE, En A. Burnout and psychological distress among nurses in a Nigerian tertiary health institution. Afr Health Sci. 2014 Mar; 14(1): 237-45. PMid:26060486 http://dx.doi .org/10.4314/a hs.v14i1.37

[49] Adekola B. Gender differences in the experience of work burnout among university staff. Afr J Bus Manag. 2009; 4(6): 886-889.

[50] Jaramillo F, Mulki JP, Boles JS. Workplace stressors, job attitude, and job behaviors: is interpersonal conflict the missing link? J Pers Sel Sales Manag. 2011 Jun 1; 31(3): 339-56. http://dx.doi.org /10.2753/PSS0885-3134310310

[51] Mohammad SI, Al-Zeaud HA, Batayneh AM. The relationship between transformational leadership and employees' satisfaction at Jordanian private hospitals. Bus Econ Horiz. 2011 Apr 1; 5(2): 35-46. http://dx.doi.org/10.15208/beh.2011.13

[52] AbuAlRub RF, Al-Zaru IM. Job stress, recognition, job performance and intention to stay at work among Jordanian hospital nurses. J Nurs Manag. 2008 Apr 1; 16(3): 227-36. PMid:18324981 http://dx.doi.org/10.1111/j.1365-2834.2007.00810.x

[53] Mansoor M, Fida S, Nasir S, et al. The impact of job stress on employee job satisfaction a study on telecommunication sector of Pakistan. J Bus Stud Quart. 2011 Jun 1; 2(3): 50.

[54] Bashir U, Ramay MI. Impact of Stress on Employees Job Performance A Study on Banking Sector of Pakistan. Inter J Market Stud. 2010 May 2; 2(1): 122-6. http://dx.doi.org/10.5539/ijms. v2n1p122

[55] Ahsan N, Abdullah Z, Fie DG, et al. A study of job stress on job satisfaction among university staff in Malaysia: Empirical study. Eur J Soci Sci. 2009; 8(1): 121-31.

[56] Yozgat U, Yurtkoru S, Bilginoğlu E. Job stress and job performance among employees in public sector in Istanbul: examining the moderating role of emotional intelligence. Proced Soc Behav Sci. 2013 Apr 3; 75: 518-24. http://dx.doi.org/10.1016/j. sbspro. 2013 .04 .056
[57] Nadinloyia KB, Sadeghib H, Hajlooc N. Relationship between job satisfaction and employees mental Health. Proced Soc Behav Sci. 2013; 84(9): 293-7. http://dx.doi.org/10.1016/j.sbspro. 2013.06.554

[58] Bernhard F, O'Driscoll MP. Psychological ownership in small familyowned businesses: Leadership style and nonfamily-employees' work attitudes and behaviors. Gr Organ Manag. 2011 Jun 1; 36(3): 345-84 http://dx.doi.org/10.1177/1059601111402684

[59] Mrayyan MT. Job stressors and social support behaviors: Comparing intensive care units to wards in Jordan. Contemp Nurse. $2009 \mathrm{Feb} 1$; 31(2): 163-75. PMid:19379118 http://dx.doi .org/10.5172/c onu.673.31.2.163

[60] Rao S, Borkar S. Development of scale for measurement of stress and performance status of public and private sector bank employees. India Stream Res J. 2012; 2(7): 1-7.

[61] Lemieux-Charles L, McGuire WL. What do we know about health care team effectiveness? A review of the literature. Med Care Res Rev. 2006 Jun 1; 63(3): 263-300. PMid:16651394 http: //dx.doi.org/10.1177/1077558706287003

[62] Körner M. Analysis and development of multi-professional teams in medical rehabilitation. GMS Psycho Soc Med. 2008; 5: 2008-5.

[63] Kauffeld S, Schulte DPEM. Teams and their development. In: Work, Organizational and Personnel Psychology for Bachelor. Springer Berlin Heidelberg; 2014. pp. 151-71.

[64] Chang WY, Ma JC, Chiu HT, et al. Job satisfaction and perceptions of quality of patient care, collaboration and teamwork in acute care hospitals. J Adv Nurs. 2009 Sep 1; 65(9): 1946-55. PMid:19694858 http://dx.doi.org/10.1111/j.1365-2648.2009.05085.x

[65] Körner M. Inter-professional teamwork in medical rehabilitation: a comparison of multidisciplinary and interdisciplinary team approach. Clin Rehabil. 2010 Jun 8. PMid:20530646 http://dx.doi.org/1 $0.1177 / 0269215510367538$

[66] Aiken LH, Sloane DM, Bruyneel L, et al. Nurses' reports of working conditions and hospital quality of care in 12 countries in Europe. Inter J Nurs Stud. 2013 Feb 28; 50(2): 143-53. PMid:23254247 http://dx.doi.org/10.1016/j.ijnurstu.2012.11.009

[67] Manser T. Teamwork and patient safety in dynamic domains of healthcare: a review of the literature. Acta Anaesthesiol Scand. $2009 \mathrm{Feb}$ 1; 53(2): 143-51. PMid:19032571 http://dx.doi.org/10.1111 /j.1399-6576.2008.01717.x

[68] Koerner M. Mental strain among staff at medical rehabilitation clinics in Germany. GMS Psych-Soc Med. 2011; 8.

[69] Salas E, Gregory ME, King HB. Team training can enhance patient safety-the data, the challenge ahead. Joint Comm J Qual Patient Saf/Joint Comm Resour. 2011 Aug; 37(8): 339-40.

[70] O'Leary KJ, Sehgal NL, Terrell G, et al. Interdisciplinary teamwork in hospitals: a review and practical recommendations for improvement. J Hosp Med. 2012 Jan 1; 7(1): 48-54. PMid:22042511 http://dx.doi.org/10.1002/jhm.970

[71] Quaschning K, Körner M, Wirtz M. Analyzing the effects of shared decision-making, empathy and team interaction on patient satisfaction and treatment acceptance in medical rehabilitation using a structural equation modeling approach. Patient Edu Counsel. 2013 May 31; 91(2): 167-75. PMid:23318156 http://dx.doi.org/10.10 $16 / j \cdot$ pec. 2012.12 .007 